\title{
A White Killer Whale in the Central Aleutians
}

\author{
MARTIN RENNER ${ }^{1,2}$ and KEVIN BELL ${ }^{3}$
}

(Received 25 April 2007; accepted in revised form 26 June 2007)

\begin{abstract}
We observed a white adult male killer whale (Orcinus orca) on 7 August 2000 off the north side of Adak Island, Aleutians. An open saddle and a rounded dorsal fin tip suggest that this whale belongs to the fish-eating ("resident") ecotype. A circular scar matching a cookie-cutter shark (Isistius sp.) bite mark suggested that the animal originated in warmer waters. Photographs and description provided here should enable individual identification should this animal be seen again.
\end{abstract}

Key words: killer whale, Orcinus orca, pigmentation anomaly, cookie-cutter shark, Isistius sp., Aleutian Archipelago

RÉSUMÉ. Le 7 août 2000, nous avons observé un épaulard adulte mâle de couleur blanche (Orcinus orca) du côté nord de l'île Adak, îles Aléoutiennes. Sa selle ouverte et sa nageoire dorsale arrondie laissaient croire que cette baleine faisait partie de l'écotype des baleines mangeant des poissons ( «ésident»). Une cicatrice circulaire correspondant à une morsure de squaletet (Isistius sp.) laissait présumer que l'animal provenait d'eaux plus chaudes. Les photographies et la description fournies ici devraient permettre une identification individuelle advenant que cet épaulard soit aperçu de nouveau.

Mots clés : épaulard, Orcinus orca, anomalie de la pigmentation, squaletet, Isistius sp., îles Aléoutiennes

Traduit pour la revue Arctic par Nicole Giguère.

On 7 August 2000, we observed an almost all-white male killer whale (Orcinus orca) on the north side of Adak Island (off Cape Adagdak) $\left(52^{\circ} 01.1^{\prime} \mathrm{N}, 176^{\circ} 35.0^{\prime} \mathrm{W}\right)$, central Aleutians, Alaska. We sighted the animal from a distance of about $1 \mathrm{~km}$, within a group of about 15 individuals (at least 12, maximum 20 individuals) that included at least one other male. We did not get a direct comparison with the other male, but the white whale was clearly larger than any of the accompanying females. The height-to-width ratio of the dorsal fin (averaged from two photographs following Olesiuk et al., 1990) was 1.65. No other animal in the group showed atypical pigmentation. We were able to stay with the group for about half an hour, during which the white whale once approached our vessel within a distance of about $50 \mathrm{~m}$. The other individuals of the widely scattered group stayed farther away and were not photographed.

While the whale appeared pure white from a distance, the characteristic black markings were visible as a tan shadow on close approach. Besides its lack of pigmentation, photographs revealed several distinct marks: 1) a rake scar of five parallel scratches on the left side near the trailing edge of the dorsal fin; 2) what appeared to be the bite of a cookie-cutter shark (Isistius brasiliensis or I. plutodus) behind the blow hole; 3) an "open saddle," i.e., a dark swirl entering the saddle dorsally (Fig. 1). The latter mark could aid subsequent individual identification should this animal be sighted again. Adak-based fishermen reported the white killer whale on at least one occasion within five days of our initial sighting. We have not seen this individual since that day, although we have passed the area at least six times every summer and encountered killer whales frequently.

Sightings of white cetaceans are rare, but they have been reported for a large number of species (Hain and Leatherwood, 1982; Fertl et al., 1999, 2004). White killer whales have previously been reported from the state of Washington, as well as from British Columbia, New Zealand, and the Azores (Fertl et al., 1999, and references within). In August 1997, a white male killer whale was seen off St. Lawrence Island in the northern Bering Sea (Speckman and Sheffield, 2001). Its skin was described as "creamy yellowish," with shadows of the normal patterns as well. The individual described here showed similar residual pigmentation. However, since no photographs were taken in August 1997, it cannot be determined whether that whale was the same individual.

A free-ranging white killer whale ("Chimo"), which died in captivity, was diagnosed with Chédiak-Higashi Syndrome, an inherited fatal disorder characterized by diluted pigmentation and reduced life span (Taylor and Farrell, 1973; Ridgway, 1979). Size and height-to-width ratio of the dorsal fin indicate that our Aleutian white killer whale was fully grown and therefore at least 20 years old (Olesiuk et al., 1990). This age suggests a different cause, rather than Chédiak-Higashi Syndrome, for the lack of pigmentation.

\footnotetext{
${ }^{1}$ Department of Biology, Memorial University of Newfoundland, St. John's, Newfoundland A1B 3X9, Canada; present address: School of Aquatic and Fishery Sciences, University of Washington, Box 351800, Seattle, Washington 98195, USA

${ }^{2}$ Corresponding author: auklet@bigfoot.com

${ }^{3}$ Alaska Maritime National Wildlife Refuge, 95 Sterling Highway, Suite 1, Homer, Alaska 99603, USA

(C) The Arctic Institute of North America
} 

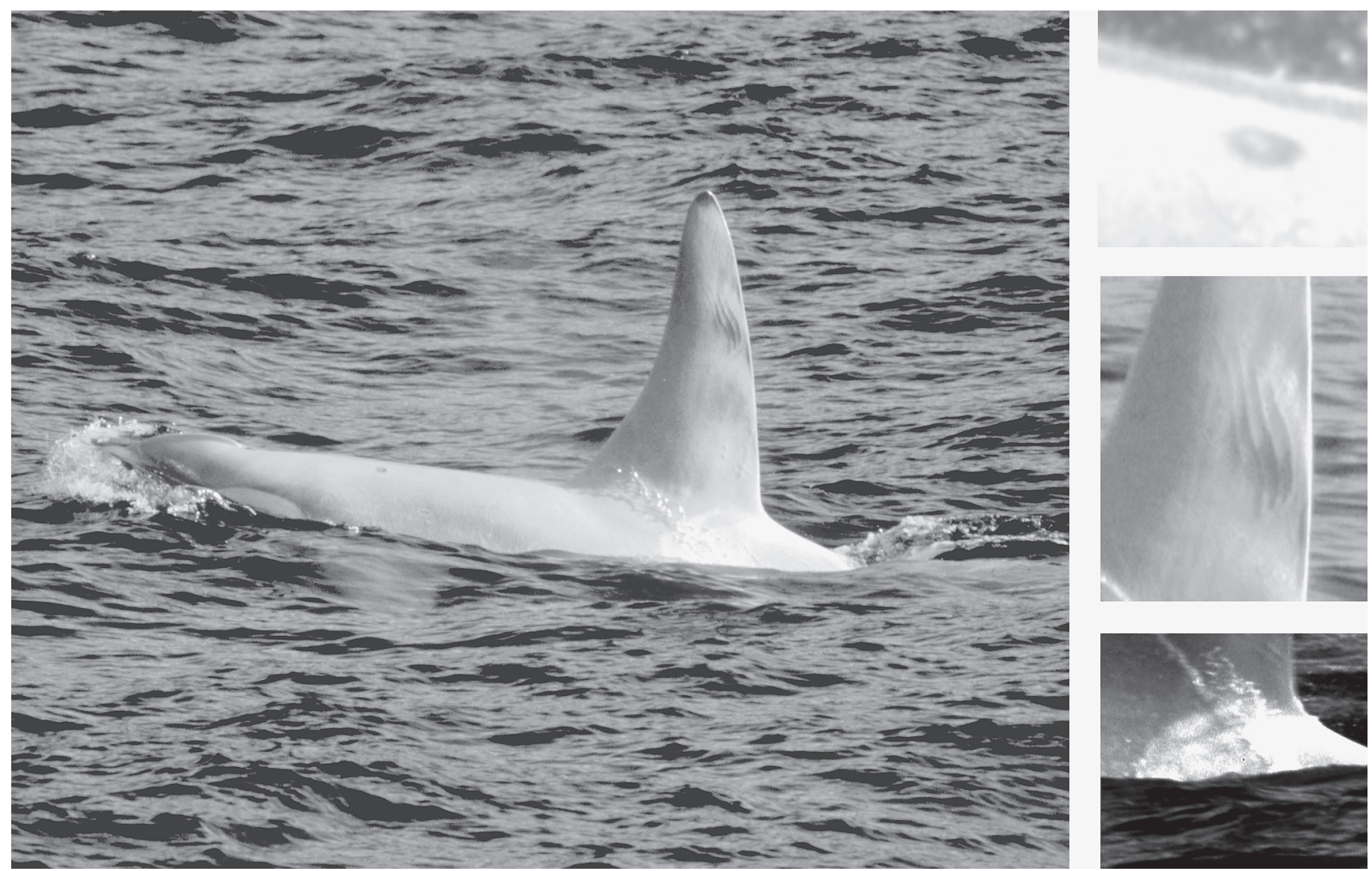

FIG. 1. White male killer whale (Orcinus orca) off Adak Island, central Aleutians. Note the cookie-cutter shark (Isistius sp.) bite mark behind the blowhole, scratch marks on the dorsal fin, and the "open saddle." The inserts were collected from other frames. Contrast was enhanced on the saddle insert. (Photographs: M. Renner)

The open saddle seen on this white male is not found in mammal-eating (so-called "transient") killer whales (Baird and Stacey, 1988; Ford et al., 2000; Matkin et al., 2007), suggesting that this individual belongs to one of the fisheating types ("resident" or "offshore") found in the temperate coastal waters of the North Pacific. This designation is also supported by the rounded shape of the dorsal fin tip. The fish-eating "resident" type of killer whale is also the most abundant ecotype in the eastern and central Aleutians (Zerbini et al., 2007).

The near-circular dorsal mark behind the white whale's blowhole fits the characteristics of a cookie-cutter shark bite mark (Jones, 1971). Cookie-cutter sharks prefer tropical to temperate waters. The few records of their presence in the North Pacific are all from the warmer waters of the Transition Domain, or even farther south (Favorite et al., 1976; Nakano and Tabuchi, 1990; Ocean Biogeographic Information System [OBIS], http://www.iobis.org/). Thus it seems likely that this whale came to the Aleutians from warmer deep waters, probably south of $40^{\circ} \mathrm{N}$, before its scar could heal. In contrast to killer whales living along the west coast of North America, those found around the Hawaiian Islands commonly show cookie-cutter shark scars (Baird et al., 2006). Cookie-cutter shark bites have also been found in large numbers on Stejneger's beaked whales (Mesoplodon stejnegeri) beached on Adak Island; these were interpreted as evidence for migration to warmer waters (Walker and Hanson, 1999).

Given that a) neither we nor others have encountered this white killer whale in the Aleutian Archipelago before or since 7 August 2000, b) a white male killer whale, possibly the same individual, was observed in the northern Bering Sea in 1997 (Speckman and Sheffield, 2001), and c) the whale bears a putative cookie-cutter shark mark, we speculate that this individual is highly mobile and travels over a wide range in the North Pacific. Because male killer whales can live for 50 to 60 years (Olesiuk et al., 1990) this individual could be seen again for a long time to come. That it took so long to document this more than 20-year-old white individual is a reminder of how little is known about killer whales and their diet, seasonal movements, and habitat use in the Bering Sea. The recent controversy surrounding killer whales and the decline of other marine mammal species (Estes et al., 1998; Springer et al., 2003; Wade et al., 2007; Trites et al., 2007) highlights the need for these data.

\section{ACKNOWLEDGEMENTS}

We would like to thank the crew of the M/V Tighlâx. R. Baird, M. Dahlheim, D. Fertl, H. Renner, J. Williams, and an anonymous reviewer provided helpful comments that improved the manuscript. 


\section{REFERENCES}

BAIRD, R.W., and STACEY, P.J. 1988. Variation in saddle patch pigmentation in populations of killer whales (Orcinus orca) from British Columbia, Alaska, and Washington State. Canadian Journal of Zoology 66:2582-2585.

BAIRD, R.W., McSWEENEY, D., BANE, C., BARLOW, J., SALDEN, D., ANTOINE, L., LEDUC, R., and WEBSTER, D. 2006. Killer whales in Hawaiian waters: Information on population identity and feeding habits. Pacific Science 60: $523-530$.

ESTES, J.A., TINKER, M.T., WILLIAMS, T.M., and DOAK, D.F. 1998. Killer whale predation on sea otters linking oceanic and nearshore ecosystems. Science 282:473-476.

FAVORITE, F., DODIMEAD, A.J., and NASU, K. 1976. Oceanography of the subarctic Pacific region, 1960-1971. International North Pacific Fisheries Commission Bulletin 33: $1-187$.

FERTL, D., PUSSER, L.T., and LONG, J.J. 1999. First record of an albino bottlenose dolphin Turssiops truncatus in the Gulf of Mexico, with a review of anomalously white cetaceans. Marine Mammal Science 15:227-234.

FERTL, D., BARROS, N.B., ROWLETT, R.A., ESTES, S., and RICHLEN, M. 2004. An update on anomalously white cetaceans, including the first account for the pantropical spotted dolphin (Stenella attenuata graffmani). Latin American Journal of Aquatic Mammals 3:163-166.

FORD, J.K.B., ELLIS, G.M., and BALCOMB, K.C. 2000. Killer whales: The natural history and genealogy of Orcinus orca in British Columbia and Washington State. Vancouver, British Columbia: UBC Press.

HAIN, J.H.W., and LEATHERWOOD, S. 1982. Two sightings of white pilot whales, Globicephala melaena, and summarized records of anomalously white cetaceans. Journal of Mammalogy 63:338-343.

JONES, E.C. 1971. Isistius brasiliensis, a squaloid shark, the probable cause of crater wounds on fishes and cetaceans. Fishery Bulletin 69:791-798.

MATKIN, C.O., BARRETT-LENNARD, L.G., YURK, H., ELLIFRIT, D., and TRITES, A.W. 2007. Ecotypic variation and predatory behavior of killer whales (Orcinus orca) in the eastern Aleutian Islands, Alaska. Fishery Bulletin 105:74-87.

NAKANO, H., and TABUCHI, M. 1990. Occurrence of the cookiecutter shark Isistius brasiliensis in surface waters of the North Pacific Ocean. Japanese Journal of Ichthyology 37: $60-63$.
OLESIUK, P.F., BIGG, M.A., and ELLIS, G.M. 1990. Life history and population dynamics of resident killer whales (Orcinus orca) in the coastal waters of British Columbia and Washington State. Reports of the International Whaling Commission, Special Issue 12:209-242.

RIDGWAY, S.H. 1979. Reported causes of death of captive killer whales (Orcinus orca). Journal of Wildlife Diseases 15: 99-104.

SPECKMAN, S.G., and SHEFFIELD, G. 2001. First record of an anomalously white killer whale, Orcinus orca, near St. Lawrence Island, northern Bering Sea, Alaska. Canadian Field-Naturalist 115:501-502.

SPRINGER, A.M., ESTES, J.A., VAN VLIET, G.B., WILLIAMS, T.M., DOAK, D.F., DANNER, E., FORNEY, K.A., and PFISTER, B. 2003. Sequential megafauna collapse in the North Pacific Ocean: An ongoing legacy of industrial whaling? Proceedings of the National Academy of Sciences of the United States of America 100:12223-12228.

TAYLOR, R.F., and FARRELL, R.K. 1973. Light and electron microscopy of peripheral blood neutrophils in a killer whale affected with Chediak-Higashi Syndrome. Federation Proceedings 32:822.

TRITES, A.W., DEECKE, V.B., GREGR, E.J., FORD, J.K.B., and OLESIUK, P.F. 2007. Killer whales, whaling, and sequential megafaunal collapse in the North Pacific: A comparative analysis of the dynamics of marine mammals in Alaska and British Columbia following commercial whaling. Marine Mammal Science 23:751-765.

WADE, P.R., BURKANOV, V.N., DAHLHEIM, M.E., FRIDAY, N.A., FRITZ, L.W., LOUGHLIN, T.R., MIZROCH, S.A., MUTO, M.M., RICE, D.W., BARRETT-LENNARD, L.G., BLACK, N.A., BURDIN, A.M., CALAMBOKIDIS, J., CERCHIO, S., FORD, J.K.B., JACOBSEN, J.K., MATKIN, C.O., MATKIN, D.R., MEHTA, A.V., SMALL, R.J., STRALEY, J.M., McCLUSKEY, S.M., VANBLARICOM, G.R., and CLAPHAM, P.J. 2007. Killer whales and marine mammal trends in the North Pacific-A re-examination of evidence for sequential megafauna collapse and the prey-switching hypothesis. Marine Mammal Science 23:766-802.

WALKER, W.A., and HANSON, M.B. 1999. Biological observations on Stejneger's beaked whale, Mesoplodon stejnegeri, from strandings on Adak Island, Alaska. Marine Mammal Science 15:1314-1329.

ZERBINI, A.N., WAITE, J.M., DURBAN, J.W., LEDUC, R.G., DAHLHEIM, M.E., and WADE, P.R. 2007. Estimating abundance of killer whales in the nearshore waters of the Gulf of Alaska and Aleutian Islands using line transect sampling. Marine Biology 150:1033-1045. 